DOI: 10.12731/2658-4034-2020-3-40-43

\title{
О ХАРАКТЕРИСТИКАХ МЕТОДОВ ДИСТАНЦИОННОГО ОБУЧЕНИЯ
}

\author{
Преображенский А.П. ${ }^{1}$, Чопоров О.Н. ${ }^{2}$
}

${ }^{1}$ Воронежский институт высоких технологий,

г. Воронеж, Российская Федерация

${ }^{2}$ Воронежский государственный технический университет,

г. Воронеж, Российская Федерация

В данной работе проведено рассмотрение возможностей применения некоторых образовательных подходов в современных условиях. Показана роль дистаниионных технологий.

Ключевые слова: образовательная система; обучающийся; методика; технология.

\section{ABOUT CHARACTERISTICS OF DISTANCE EDUCATIONAL APPROACHES}

\section{Preobrazhenskiy A.P. ${ }^{1}$, Choporov O.N. ${ }^{2}$}

${ }^{1}$ Voronezh Institute of High Technologies, Voronezh, Russia ${ }^{2}$ Voronezh State Technical University, Voronezh, Russian Federation

In this paper, we consider the possibilities of using some educational approaches in modern conditions. The role of remote technologies is shown.

Keywords: educational system; student; methodology; technology.

\section{Введение}

На современное образование оказывает влияние множество факторов. Прежде всего - это развивающиеся технологии. Но еще другим важным фактором можно считать изменяющиеся условия, 
в которых живут люди. В статье проводится анализ возможностей применения разных, представляющих интерес, методик и методов в образовательной среде.

\section{О характеристиках некоторых подходов в образовании}

Подходы, связанные с дистанционным образованием, в своем развитии уже претерпели несколько этапов. Есть возможности утверждать, что сложились принципы, которые применяются и подтверждаются на практике уже в течение ряда лет.

Подобные технологии являются весьма гибкими, использующими целый спектр возможностей.

Применение технологий виртуальной или дополненной реальности открывает новые стороны в образовательном процессе. Следует указать, что именно на базе подобных технологий, например, подготовка профессиональных спортсменов выходит на совершенно другой, ранее недостижимый уровень.

Конечно, создатели образовательных курсов должны стремиться к к тому, чтобы разнородные составляющие, образующие целостную образовательную систему, были спроектированы так, чтобы среди них проводилась поддержка качественной работы.

При этом будут добавляться новые компоненты, которые органичным образом будут входить в образовательный процесс, что ведет к привлекательности на рынке образовательных услуг [1].

Не всегда обучающиеся имеют возможности для того, чтобы проходить обучение в рамках крупных образовательных центрах, в больших городах. На основе разработок информационно-телекоммуникационных технологий можно говорить о росте популярности дистанционного обучения [2].

Сейчас обучающиеся создают в информационной среде вуза личный кабинет, обладают большой мобильностью, имеют возможности для того, чтобы слушать лекции педагогов из любой точки мира $[3,4]$.

Во многих курсах, которые поддерживаются крупными вендорами, предусмотрено выполнение лабораторных работ в специализированных средах. 
При этом обучающиеся не испытывают никакого дискомфорта при процессах обучения, оно весьма близко к тому, которое есть в традиционных подходах [5].

Тьюторы находятся в контакте с обучающимися, отвечают на возникающие вопросы. Ведется поддержка формирования индивидуальных траекторий среди обучающихся.

Информационные технологии должны применяться в ходе занятий обучающимися научной работой.

\section{Выводы}

На основе применения различных подходов образовательная система становится более гибкой и возникают дополнительные возможности для того, чтобы полноценным образом планировать как индивидуальные траектории обучающихся, так и различные ресурсы, которые будут применяться преподавателями.

\section{Список литературы}

1. Преображенский Ю.П. Характеристики информационно-образовательного пространства вуза // В сборнике: Антропоцентрические науки: инновационный взгляд на образование и развитие личности Материалы VII Международной научно-практической конференции. 2018. С. 218-219.

2. Преображенский Ю.П. О подготовке инженерных кадров // В сборнике: Современные инновации в науке и технике Сборник научных трудов 8-й Всероссийской научно-технической конференции с международным участием. Ответственный редактор А.А. Горохов. 2018. С. $175-179$.

3. Преображенский Ю.П., Преображенская Н.С., Львович И.Я. Некоторые аспекты информатизации образовательных учреждений и развития медиакомпетентности преподавателей и руководителей // Вестник Воронежского государственного технического университета. 2013. T. 9. № 5-2. С. 134-136.

4. Максимова И.В., Ваганова О.И., Карпова М.А. Использование видеофрагментов при преподавании дисциплин естественнонаучного 
цикла // Современные исследования социальных проблем (электронный научный журнал). 2018. Т. 9. № 9-2. С. 56-59.

5. Якушева С.Д. Самоменеджмент в деятельности педагога современного образовательного комплекса // Современные исследования социальных проблем (электронный научный журнал). 2018. Т. 9. № 11. С. 242-263.

\section{References}

1. Preobrazhenskij Yu.P. Harakteristiki informacionno-obrazovatel'nogo prostranstva vuza // V sbornike: Antropocentricheskie nauki: innovacionnyj vzglyad na obrazovanie i razvitie lichnosti Materialy VII Mezhdunarodnoj nauchno-prakticheskoj konferencii. 2018. S. 218-219.

2. Preobrazhenskij Yu.P. O podgotovke inzhenernyh kadrov // V sbornike: Sovremennye innovacii v nauke i tekhnike Sbornik nauchnyh trudov 8-j Vserossijskoj nauchno-tekhnicheskoj konferencii s mezhdunarodnym uchastiem. Otvetstvennyj redaktor A.A. Gorohov. 2018. S. 175-179.

3. Preobrazhenskij Yu.P., Preobrazhenskaya N.S., L'vovich I.Ya. Nekotorye aspekty informatizacii obrazovatel'nyh uchrezhdenij i razvitiya mediakompetentnosti prepodavatelej i rukovoditelej // Vestnik Voronezhskogo gosudarstvennogo tekhnicheskogo universiteta. 2013. T. 9. № 5-2. S. 134-136.

4. Maksimova I.V., Vaganova O.I., Karpova M.A. Ispol'zovanie videofragmentov pri prepodavanii disciplin estestvennonauchnogo cikla // Sovremennye issledovaniya social'nyh problem (elektronnyj nauchnyj zhurnal). 2018. T. 9. № 9-2. S. 56-59.

5. Yakusheva S.D. Samomenedzhment v deyatel'nosti pedagoga sovremennogo obrazovatel'nogo kompleksa // Sovremennye issledovaniya social'nyh problem (elektronnyj nauchnyj zhurnal). 2018. T. 9. № 11. S. 242-263. 